\title{
PENGARUH JARAK TANAM DAN KEDALAMAN LUBANG TANAM TERHADAP PERTUMBUHAN DAN PRODUKSI JAGUNG MANIS (Zea mays saccharata Sturt.)
}

\author{
Eliakim Purba \\ Eliakim_purba@yahoo.com \\ Universitas Amir Hamzah
}

\begin{abstract}
Abstrak
Tujuan penelitian untuk mengetahui respon pertumbuhan dan produksi jagung manis (Zea mays saccharata Sturt.) pada berbagai jarak tanam dan kedalaman lubang tanam. Penelitian ini menggunakan Rancangan Acak Kelompok (RAK) faktorial yang terdiri dari dua faktor yaitu: Faktor pertama jarak tanam dengan notasi $(J)$ yang terdiri dari 3 taraf yaitu: $J_{1}=70 \times 30 \mathrm{~cm}, J_{2}=70 \times 40 \mathrm{~cm}$, dan $J_{3}=70 \times 50 \mathrm{~cm}$. Faktor kedua kedalaman lubang tanam dengan notasi $(K)$ yang terdiri dari 4 taraf yaitu : $K_{1}=3 \mathrm{~cm}, K_{2}=5 \mathrm{~cm}, K_{3}=7 \mathrm{~cm}$, dan $K_{4}=9 \mathrm{~cm}$. Parameter yang diamati yaitu tinggi tanaman $(\mathrm{cm})$, diameter pangkal batang $(\mathrm{mm})$, berat tongkol berkelobot per tanaman $(\mathrm{g})$, berat tongkol tanpa kelobot per tanaman $(\mathrm{g})$, panjang tongkol $(\mathrm{cm})$, dan produksi per plot $(\mathrm{kg})$. Hasil penelitian menunjukkan bahwa interaksi antara jarak tanam dan kedalaman lubang tanam memberikan respon yang nyata terhadap parameter tinggi tanaman umur 30 HST. Kombinasi perlakuan terbaik yaitu $J_{3} K_{2}$ (jarak tanam $70 \times 50 \mathrm{~cm}$ dan kedalaman lubang tanam $5 \mathrm{~cm}$. Hasil penelitian menunjukkan produksi tanaman jagung manis yang tertinggi yaitu menggunakan jarak tanam $70 \times 30 \mathrm{~cm}$ dengan kedalaman lubang tanam $5 \mathrm{~cm}$ yang dilakukan secara bersamaan.
\end{abstract}

Kata Kunci : Jarak Tanam, Kedalaman Lubang Tanam, Jagung Manis (Zea mays)

\section{PENDAHULUAN}

Kebutuhan pasar yang meningkat dan nilai ekonomis yang tinggi membuat jagung manis perlu dikembangkan untuk meningkatkan hasil atau produksinya. Akan tetapi selain meningkatkan hasil atau produksi perlu dikembangkan juga bagaimana teknik untuk peningkatan kualitas dari jagung manis tersebut (Paradipta $d k k$., 2013).Salah satu cara meningkatkan produksi jagung manis yaitu dengan memperhatikan teknik budidaya seperti pengaturan jarak tanam.

Pengaturan jarak tanam pada suatu areal tanah pertanian merupakan salah satu cara yang berpengaruh terhadap hasil yang akan dicapai. Makin rapat jarak tanam menyebabkan lebih banyak tanaman yang tidak berbuah. Harjadi (2002) mengatakan bahwa jarak tanam juga mempengaruhi persaingan antar tanaman dalam mendapatkan air dan unsur hara, sehingga akan mempengaruhi hasil.

Penggunaan jarak tanam pada tanaman jagung manis perlu diperhatikan untuk 
mendapatkan pertumbuhan tanaman yang seragam, distribusi unsur hara yang merata, efektivitas penggunaan lahan, memudahkan pemeliharaan dan menekan perkembangan hama dan penyakit. Menurut Nurlaili (2010), penggunaan jarak tanam yang terlalu rapat antara daun sesama tanaman saling menutupi akibatnya pertumbuhan tanaman akan tinggi memanjang karena bersaing dalam mendapatkan cahaya sehingga akan menghambat proses fotosintesis dan produksi tanaman tidak optimal.

Hasil penelitian Azis dan Arman (2013), didapatkan bahwa jarak tanam berpengaruh terhadap pertumbuhan dan produksi tanaman jagung manis. Perlakuan terbaik didapatkan pada jarak tanam $70 \times 40 \mathrm{~cm}$, dimana pada jarak tanam tersebut dapat mengurangi kompetisi pengambilan unsur hara, air dan cahaya baik antara tanaman itu sendiri maupun dengan tanaman lainnya sehingga dapat mengoptimalkan pertumbuhan dan produksi.

Selain pengaturan jarak tanam, kedalaman lubang tanam dalam penanaman benih pada budidaya jagung manis juga merupakan salah satu upaya untuk meningkatkan pertumbuhan dan produksi tanaman jagung manis. Menurut Santoso dan Purwoko (2008), pengaturan kedalaman peletakan benih dalam lubang tanam sangat mempengaruhi pertumbuhan dan perkembangan awal bibit, menentukan kualitas sistim perakaran dan mempengaruhi jumlah semai yang berhasil tumbuh.

Hasil penelitian Pratama $d k k$. (2014), didapatkan bahwa kedalaman penanaman benih jagung manis menimbulkan perbedaan yang nyata hanya pada fase pertumbuhan, tetapi tidak terdapat perbedaan yang signifikan pada hasil jagung manis. Dari perlakuan kedalaman penanaman yang diuji yaitu 1, 3, 5 dan $7 \mathrm{~cm}$, perlakuan terbaik didapatkan pada kedalaman lubang tanam $5 \mathrm{~cm}$.

Penelitian ini bertujuan untuk mengetahui respon pertumbuhan dan produksi jagung manis (Zea mays saccharata Sturt.) pada berbagai jarak tanam dan kedalaman lubang tanam.

\section{BAHAN DAN METODE PENELITIAN}

\subsection{Tempat dan Waktu Penelitian}

Penelitian ini dilaksanakan di Kebun Percobaan Fakultas Pertanian Universitas Amir Hamzah, Medan dengan ketinggian tempat $\pm 25 \mathrm{~m}$ di atas permukaan laut dengan topografi datar. Penelitian ini dilaksanakan pada bulan April sampai bulan Juli 2020.

Bahan dan Alat

\subsection{Bahan dan Alat}

Bahan-bahan yang digunakan dalam penelitian ini adalah: Benih jagung varietas Mutiara 511 produksi PT Djimat Seed Indonesia, pupuk kandang sapi, pupuk Urea, pupuk TSP, pupuk KCl, Insektisida Sevin 85 S dan Fungisida Dithane M-45 80 WP, cat, paku, tali plastik, papan nama serta papan perlakuan. Alat-alat yang digunakan dalam penelitian ini meliputi : kamera, babat, gunting, cangkul, garu, handsprayer, timbangan digital, jangka sorong, meteran, gembor dan alat tulis menulis.

\subsection{Metode Penelitian}

Penelitian ini menggunakan Rancangan Acak Kelompok (RAK) faktorial yang terdiri dari dua faktor yaitu :

1. Faktor jarak tanam dengan notasi ( $\mathrm{J})$ yang terdiri dari 3 taraf yaitu: 


$$
\begin{aligned}
& \mathrm{J}_{1}=70 \times 30 \mathrm{~cm} \\
& \mathrm{~J}_{2}=70 \times 40 \mathrm{~cm} \\
& \mathrm{~J}_{3}=70 \times 50 \mathrm{~cm}
\end{aligned}
$$

2. Faktor kedalaman lubang tanam dengan notasi (K) yang terdiri dari 4 taraf yaitu :

$\mathrm{K}_{1}=3 \mathrm{~cm}$

$\mathrm{K}_{2}=5 \mathrm{~cm}$

$\mathrm{K}_{3}=7 \mathrm{~cm}$

$\mathrm{K}_{4}=9 \mathrm{~cm}$

Dengan demikian diperoleh 12 kombinasi perlakuan yang diulangi 3 kali sehingga diperoleh 36 satuan percobaan dan sebagai tanaman sampel di ambil secara acak 3 tanaman per plot. Data hasil pengamatan dianalisis secara statistik dengan menggunakan Analisis Sidik Ragam atau Uji F pada tingkat signifikan 5\% dan $1 \%$. Jika hasil Uji F terhadap parameter yang diamati berpengaruh nyata dan sangat nyata, maka dilanjutkan dengan Uji Beda Nyata Jujur (BNJ) taraf 5\%.

\section{Aplikasi Perlakuan \\ Jarak Tanam}

Jarak tanam yang digunakan seperti perlakuan yaitu $\mathrm{J}_{1}=70 \times 30 \mathrm{~cm}, \mathrm{~J}_{2}=70 \times 40 \mathrm{~cm}$ dan $J_{3}=70 \times 50 \mathrm{~cm}$. Jumlah tanaman untuk plot yang jarak tanam $70 \times 30 \mathrm{~cm}$ yaitu 8 tanaman dan untuk jarak tanam $70 \mathrm{~cm} \times 40 \mathrm{~cm}$ yaitu 6 tanaman sedangkan jarak tanam $70 \mathrm{~cm}$ x $50 \mathrm{~cm}$ yaitu 4 tanaman.

\section{Kedalaman Lubang Tanam}

Kedalaman lubang tanam yang digunakan seperti perlakuan yaitu $\mathrm{K}=3 \mathrm{~cm}$, $\mathrm{K}_{2}=5 \mathrm{~cm}, \mathrm{~K}_{3}=7 \mathrm{~cm}$ dan $\mathrm{K}_{4}=9 \mathrm{~cm}$. Pembuatan lubang tanam dilakukan dengan menggunakan tugal yang disiapkan menurut perlakuan kedalaman lubang tanam, dengan cara membuat pembatas di ujung tugal.

\section{Penanaman}

Penanaman dilakukan pada sore hari dengan cara mengisi 2 butir benih tanaman pada setiap lubang tanam yang telah dipersiapkan, kemudian dilakukan penyiraman sampai kapasitas lapang. Setelah 1 minggu penanaman, dilakukan seleksi dengan memilih 1 tanaman yang pertumbuhannya paling baik untuk dipelihara sedangkan yang lainnya dipotong dengan gunting.

\section{Parameter Pengamatan}

Parameter yang diamati dalam penelitian ini adalah Tinggi Tanaman $(\mathrm{cm})$, Diameter Pangkal Batang (mm), Berat Tongkol Berkelobot per Tanaman (g), Berat Tongkol Tanpa Kelobot per Tanaman (g), Panjang Tongkol (cm) dan Produksi per Plot $(\mathrm{kg})$

\section{HASIL DAN PEMBAHASAN}

\section{Respon Pertumbuhan dan Produksi Jagung Manis akibat Jarak Tanam}

\section{Tinggi Tanaman $(\mathrm{cm})$}

Jurnal Insitusi Politeknik Ganesha Medan 
Hasil analisis ragam menunjukkan bahwa pertumbuhan tanaman jagung manis akibat perlakuan jarak tanam menunjukkan respon yang nyata pada tinggi tanaman umur 30 dan 45 HST dan tidak nyata pada umur 15 HST. Rata-rata tinggi tanaman jagung manis pada umur 15, 30 dan 45 HST akibat perlakuan jarak tanam disajikan pada Tabel 1.

Tabel 1. Rata-rata Tinggi Tanaman Jagung Manis akibat Perlakuan Jarak Tanam

\begin{tabular}{cllc}
\hline Perlakuan & \multicolumn{3}{c}{ Tinggi Tanaman $(\mathrm{cm})$} \\
\cline { 2 - 4 } & $15 \mathrm{HST}$ & $30 \mathrm{HST}$ & $45 \mathrm{HST}$ \\
\hline $\mathrm{J}_{1}$ & 20,13 & $40,06 \mathrm{a}$ & $100,19 \mathrm{a}$ \\
$\mathrm{J}_{2}$ & 20,94 & $41,42 \mathrm{ab}$ & $103,51 \mathrm{ab}$ \\
$\mathrm{J}_{3}$ & 21,02 & $43,36 \mathrm{~b}$ & $104,91 \mathrm{~b}$ \\
\hline BNJ 0,05 & tn & 2,47 & 3,66
\end{tabular}

Keterangan : Angka yang diikuti oleh huruf yang sama pada kolom yang sama berbeda tidak nyata pada uji BNJ 0,05

Tabel 1 menunjukkan bahwa tinggi tanaman jagung manis umur 30 dan 45 HST tertinggi dijumpai pada perlakuan jarak tanam $\mathrm{J}_{3}(70 \times 50 \mathrm{~cm})$ yang secara uji $\mathrm{BNJ}_{0,05}$ berbeda nyata dengan perlakuaan $J_{1}(70 \times 30 \mathrm{~cm})$, namun berbeda tidak nyata dengan perlakuan $\mathrm{J}_{2}(70 \times 40 \mathrm{~cm})$. Hal tersebut diduga pada jarak tanam 70 x $50 \mathrm{~cm}$ menghasilkan tanaman yang lebih tinggi dibandingkan pada jarak tanam 70 x $40 \mathrm{~cm}$ dan 70 x 30, karena pada jarak tanam yang lebih renggang meminimalisasi kompetisi antara tanaman dalam mendapatkan air, unsur hara dan cahaya yang diperlukan tanaman untuk proses metabolisme sehingga dapat meningkatkan pertumbuhan tinggi tanaman jagung manis.

Hal tersebut sesuai dengan pendapat Azis dan Arman (2013), jarak tanam memegang peranan penting dalam peningkatan pertumbuhan dan hasil tanaman. Penggunaan jarak tanam yang tidak teratur, mengakibatkan terjadi kompetisi baik terhadap air, unsur hara maupun cahaya di antara individu tanaman. Jarak tanam menentukan populasi tanaman dalam suatu luasan tertentu, sehingga pengaturan yang baik dapat mengurangi terjadinya kompetisi terhadap faktor-faktor tumbuh tersebut.

\section{Diameter Pangkal Batang (mm)}

Hasil analisis ragam menunjukkan bahwa pertumbuhan tanaman jagung manis akibat perlakuan jarak tanam menunjukkan respon yang tidak nyata pada diameter pangkal batang tanaman jagung manis umur 15, 30 dan 45 HST. Hal ini diduga faktor morfologi dari tanaman jagung manis bersifat lebih dominan dari pada faktor yang diujikan sehingga pengaruh yang ditimbulkan terhadap pertumbuhan diameter pangkal batang tidak terlihat. Hal ini sesuai dengan pendapat Gardner (1991) menyatakan bahwa, perkembangan tanaman dipengaruhi oleh bagaimana lingkungan tumbuhnya, namun pada saat tertentu faktor dari dalam tanaman tersebut dapat bersifat lebih dominan. Ratarata diameter pangkal batang tanaman jagung manis pada umur 15, 30 dan 45 HST akibat perlakuan jarak tanam disajikan pada Tabel 2.

Tabel 2. Rata-rata Diameter Pangkal Batang Tanaman Jagung Manis akibat Perlakuan Jarak Tanam

\begin{tabular}{llcc}
\hline \multirow{2}{*}{ Perlakuan } & \multicolumn{3}{c}{ Diameter Pangkal Batang $(\mathrm{mm})$} \\
\cline { 2 - 4 } & 15 HST & $30 \mathrm{HST}$ & $45 \mathrm{HST}$ \\
\hline
\end{tabular}




\begin{tabular}{llll}
\hline $\mathrm{J}_{1}$ & 6,67 & 12,97 & 14,78 \\
$\mathrm{~J}_{2}$ & 6,72 & 13,47 & 15,22 \\
$\mathrm{~J}_{3}$ & 6,86 & 13,31 & 15,25 \\
\hline
\end{tabular}

\section{Berat Tongkol Berkelobot per Tanaman (g)}

Hasil analisis ragam menunjukkan bahwa produksi tanaman jagung manis akibat perlakuan jarak tanam menunjukkan respon yang nyata pada berat tongkol berkelobot per tanaman. Rata-rata berat tongkol berkelobot per tanaman jagung manis akibat perlakuan jarak tanam disajikan pada Tabel 3.

Tabel 3. Rata-rata Berat Tongkol Berkelobot per Tanaman Jagung Manis akibat Perlakuan Jarak Tanam

\begin{tabular}{ll}
\hline Perlakuan & Berat Tongkol Berkelobot per Tanaman $(\mathrm{g})$ \\
\hline $\mathrm{J}_{1}$ & $350,83 \mathrm{a}$ \\
$\mathrm{J}_{2}$ & $365,83 \mathrm{ab}$ \\
$\mathrm{J}_{3}$ & $379,44 \mathrm{~b}$ \\
\hline BNJ 0,05 & 21,91 \\
\hline
\end{tabular}

Keterangan : Angka yang diikuti oleh huruf yang sama berbeda tidak nyata pada uji $\mathrm{BNJ}_{0,05}$

Tabel 3 menunjukkan bahwa berat tongkol berkelobot per tanaman jagung manis tertinggi dijumpai pada perlakuan $\mathrm{J}_{3}$ yang secara uji $\mathrm{BNJ}{ }_{0,05}$ berbeda nyata dengan perlakuaan $\mathrm{J}_{1}$, namun berbeda tidak nyata dengan perlakuan $\mathrm{J}_{2}$. Hal tersebut diduga pada jarak tanam $70 \times 50 \mathrm{~cm}$, fotosintat yang dihasilkan dari proses fotosintesis lebih besar dibandingkan pada jarak tanam yang lain sehingga menghasilkan berat tongkol yang lebih tinggi. Hal ini sesuai dengan pendapat Mayadewi (2007) yang menyatakan bahwa peningkatan berat segar tongkol baik berat tongkol berkelobot, tanpa kelobot dan berat tongkol layak jual berhubungan erat dengan besarnya fotosintat yang ditranslokasikan kebagian tongkol. Semakin besar fotosintat yang ditranslokasikan ketongkol maka semakin meningkat pula berat segar tongkol.

\section{Berat Tongkol Tanpa Kelobot per Tanaman (g)}

Hasil analisis ragam menunjukkan bahwa produksi tanaman jagung manis akibat perlakuan jarak tanam menunjukkan respon yang nyata pada berat tongkol tanpa kelobot per tanaman. Rata-rata berat tongkol tanpa kelobot per tanaman jagung manis akibat perlakuan jarak tanam disajikan pada Tabel 4.

Tabel 4. Rata-rata Berat Tongkol Tanpa Kelobot per Tanaman Jagung Manis akibat Perlakuan Jarak Tanam

\begin{tabular}{cl}
\hline Perlakuan & Berat Tongkol Tanpa Kelobot per Tanaman $(\mathrm{g})$ \\
\hline $\mathrm{J}_{1}$ & $268,06 \mathrm{a}$
\end{tabular}




\begin{tabular}{cl}
$\mathrm{J}_{2}$ & $278,89 \mathrm{ab}$ \\
$\mathrm{J}_{3}$ & $291,94 \mathrm{~b}$ \\
\hline BNJ $0,05^{2}, 84$ \\
\hline
\end{tabular}

Keterangan : Angka yang diikuti oleh huruf yang sama berbeda tidak nyata pada uji $\mathrm{BNJ}_{0,05}$

Tabel 4 menunjukkan bahwa berat tongkol tanpa kelobot per tanaman jagung manis tertinggi dijumpai pada perlakuan $\mathrm{J}_{3}$ yang secara uji $\mathrm{BNJ}{ }_{0,05}$ berbeda nyata dengan perlakuaan $\mathrm{J}_{1}$, namun berbeda tidak nyata dengan perlakuan $\mathrm{J}_{2}$. Hal ini disebabkan dengan jarak tanam yang lebih lebar $70 \times 50 \mathrm{~cm}$ menyebabkan tingkat kompetisi di antara tanaman lebih kecil dibandingkan pada jarak tanam yang lebih rapat.

Seperti dikatakan oleh Gardner $d k k$.(1991) dalam Widodo $d k k$., (2016) bahwa selain faktor genetis tanaman itu sendiri, faktor lingkungan yang berpengaruh antara lain cahaya matahari (penyinaran), kelembaban dan kesuburan tanah. Keterbatasan faktor-faktor tersebut akan berpengaruh terhadap pertumbuhan dan produksi tanaman. Selanjutnya menurut Dwijoseputro (1991), bahwa cahaya matahari sangat diperlukan dalam proses fotositesis, dengan banyaknya cahaya yang diterima tanaman maka hasil fotosintesis juga semakin banyak. Selanjutnya akan menghasilkan pertumbuhan dan hasil tanaman seperti berat tongkol tanpa kelobot yang lebih baik

\section{Panjang Tongkol (cm)}

Hasil analisis ragam menunjukkan bahwa produksi tanaman jagung manis akibat perlakuan jarak tanam menunjukkan respon yang nyata pada panjang tongkol. Rata-rata panjang tongkol tanaman jagung manis akibat perlakuan jarak tanam disajikan pada Tabel 5 .

Tabel 5. Rata-rata Panjang Tongkol Tanaman Jagung Manis akibat Perlakuan Jarak Tanam

\begin{tabular}{ll}
\hline Perlakuan & Panjang Tongkol $(\mathrm{cm})$ \\
\hline $\mathrm{J}_{1}$ & $20,12 \mathrm{a}$ \\
$\mathrm{J}_{2}$ & $20,80 \mathrm{ab}$ \\
$\mathrm{J}_{3}$ & $21,08 \mathrm{~b}$ \\
\hline BNJ 0,05 & 0,88 \\
\hline
\end{tabular}

Keterangan : Angka yang diikuti oleh huruf yang sama berbeda tidak nyata pada uji $\mathrm{BNJ}_{0,05}$

Tabel 5 menunjukkan bahwa panjang tongkol tanaman jagung manis tertinggi dijumpai pada perlakuan $\mathrm{J}_{3}$ yang secara uji $\mathrm{BNJ} \mathrm{J}_{0,05}$ berbeda nyata dengan perlakuaan $\mathrm{J}_{1}$, namun berbeda tidak nyata dengan perlakuan $\mathrm{J}_{2}$. Dari data tersebut dapat dilihat bahwa pada jarak tanam $70 \times 50 \mathrm{~cm}$ menghasilkan tongkol yang lebih panjang dibandingkan pada jarak tanam $70 \times 30 \mathrm{~cm}$ dan $70 \times 40 \mathrm{~cm}$. Hal tersebut diduga bahwa dengan pengaturan tingkat kerapatan tanaman, akan dapat mengurangi adanya kompetisi pengambilan unsur hara baik antara tanaman sendiri maupun dengan tanaman lainnya, karena jarak tanam menentukan jumlah populasi sehingga dapat mengoptimalkan pertumbuhan panjang tongkol yang didapatkan.

Hal tersebu sesuai dengan pendapat Harjadi (2002) bahwa tersedianya unsur hara dalam jumlah yang cukup dan seimbang untuk pertumbuhan tanaman menyebabkan 
proses pembelahan, pembesaran dan pemanjangan sel-sel akan berlangsung lebih baik. Selanjutnya Syarief (2006), menambahkan bahwa untuk membentuk jaringan tanaman yang lebih cepat membutuhkan beberapa unsur hara dalam jumlah yang cukup dan tersedia seperti nitrogen, kalium, fosfor dan unsur lainnya yang dibutuhkan tanaman.

\section{Produksi per Plot $(\mathrm{kg})$}

Hasil analisis ragam menunjukkan bahwa produksi tanaman jagung manis akibat perlakuan jarak tanam menunjukkan respon yang nyata pada produksi per plot. Rata-rata produksi per plot tanaman jagung manis akibat perlakuan jarak tanam disajikan pada Tabel 6.

Tabel 6. Rata-rata Produksi per Plot Tanaman Jagung Manis akibat Perlakuan Jarak Tanam

\begin{tabular}{ll}
\hline Perlakuan & Produksi per Plot $(\mathrm{kg})$ \\
\hline $\mathrm{J}_{1}$ & $1,93 \mathrm{c}$ \\
$\mathrm{J}_{2}$ & $1,67 \mathrm{~b}$ \\
$\mathrm{~J}_{3}$ & $1,18 \mathrm{a}$ \\
\hline BNJ 0,05 & 0,13
\end{tabular}

Keterangan : Angka yang diikuti oleh huruf yang sama berbeda tidak nyata pada uji BNJ 0,05

Tabel 6 menunjukkan bahwa produksi per plot tanaman jagung manis tertinggi dijumpai pada perlakuan $\mathbf{J}_{1}$ yang secara uji $\mathbf{B N J} 0,05$ berbeda nyata dengan perlakuaan $\mathbf{J}_{2}$ dan $J_{3}$. Hal tersebut karena pada jarak tanam $70 \times 30 \mathrm{~cm}$ populasi tanaman per plot yaitu 8 tanaman dan pada jarak tanam 70 x $40 \mathrm{~cm}$ menghasilkan 6 tanaman, sedangkan untuk jarak tanam 70 x $50 \mathrm{~cm}$ menghasilkan 4 tanaman. Produksi per plot yang dihasilkan berbanding lurus dengan jumlah populasi tanaman pada plot.

Hal tersebut sesuai dengan pendapat Simamora (2006), bahwa besarnya produksi per plot tanaman jagung dipengaruh oleh jumlah populasi tanaman. Untuk meningkatkan hasil tanaman jagung salah satunya yang dapat dilakukan dengan penambahan tingkat kerapatan tanaman per satuan luas. Selanjutnya Indriati (2009), menambahkan bahwa populasi tanaman akan mempengaruhi produksi suatu tanaman. Pada populasi tanaman yang tinggi akan meningkatkan produksi tanaman yang dihasilkan.

\section{Respon Pertumbuhan dan Produksi Jagung Manis akibat Kedalaman Lubang Tanam}

\section{Tinggi Tanaman $(\mathrm{cm})$}

Hasil analisis ragam menunjukkan bahwa pertumbuhan tanaman jagung manis akibat perlakuan kedalaman lubang tanam menunjukkan respon yang sangat nyata pada tinggi tanaman umur 30 HST dan nyata pada umur 15 dan 45 HST. Rata-rata tinggi tanaman jagung manis pada umur 15, 30 dan 45 HST akibat perlakuan kedalaman lubang tanam disajikan pada Tabel 7.

$\begin{aligned} & \text { Tabel 7. Rata-rata Tinggi Tanaman Jagung Manis akibat Perlakuan Kedalaman } \\
& \text { Lubang Tanam }\end{aligned}$
\begin{tabular}{cc}
\hline Perlakuan & Tinggi Tanaman $(\mathrm{cm})$ \\
\hline
\end{tabular}




\begin{tabular}{cllc}
\hline & 15 HST & 30 HST & 45 HST \\
\hline $\mathrm{K}_{1}$ & $21,07 \mathrm{ab}$ & $42,24 \mathrm{ab}$ & $103,47 \mathrm{ab}$ \\
$\mathrm{K}_{2}$ & $21,59 \mathrm{~b}$ & $43,67 \mathrm{~b}$ & $105,47 \mathrm{~b}$ \\
$\mathrm{~K}_{3}$ & $20,50 \mathrm{ab}$ & $41,26 \mathrm{ab}$ & $102,63 \mathrm{ab}$ \\
$\mathrm{K}_{4}$ & $19,63 \mathrm{a}$ & $39,28 \mathrm{a}$ & $99,90 \mathrm{a}$ \\
\hline BNJ 0,05 & 1,52 & 3,15 & 4,68
\end{tabular}

Keterangan : Angka yang diikuti oleh huruf yang sama pada kolom yang sama berbeda tidak nyata pada uji $\mathrm{BNJ}_{0,05}$

Tabel 7 menunjukkan bahwa tinggi tanaman jagung manis umur 15, 30 dan 45 HST tertinggi dijumpai pada perlakuan kedalaman lubang tanam $\mathrm{K}_{2}(5 \mathrm{~cm})$ yang secara uji BNJ 0,05 berbeda nyata dengan perlakuaan $\mathrm{K}_{4}(9 \mathrm{~cm})$, namun berbeda tidak nyata dengan perlakuan $\mathrm{K}_{1}(3 \mathrm{~cm})$ dan $\mathrm{K}_{3}(7 \mathrm{~cm})$. Hal tersebut sesuai dengan pendapat Schillinger $d k k$., (1998), menyatakan bahwa kedalaman tanam biji berpengaruh terhadap panjang koleoptil yang akhirnya mempengaruhi tinggi tanaman.

Menurut Dzwonko dan Gawronski (2002), bahwa kecambah yang lebih dahulu muncul akan memiliki laju tumbuh yang lebih baik sehingga memiliki tanaman yang lebih tinggi dibandingkan kecambah yang lebih belakang atau lambat muncul. Hal ini karena lebih dahulu dapat memanfaatkan lebih banyak cahaya.

\section{Diameter Pangkal Batang (mm)}

Hasil analisis ragam menunjukkan bahwa pertumbuhan tanaman jagung manis akibat perlakuan kedalaman lubang tanam menunjukkan respon yang tidak nyata pada diameter pangkal batang tanaman jagung manis umur 15, 30 dan 45 HST. Hal tersebut diduga pertumbuhan diameter pangkal batang tanaman jagung manis dipengaruhi oleh sifat genetis, sehingga perlakuan yang diuji tidak memberikan pengaruh yang nyata.

Hal tersebut sesuai dengan pendapat Sitompul dan Guritno (1995) menyatakan bahwa penampilan tanaman dikendalikan oleh sifat genetik di bawah pengaruh faktorfaktor lingkungan. Kendali genetik pada penampilan tanaman diekspresikan melalui proses biokimia dan fisiologis. Perbedaan susunan genetik merupakan salah satu faktor penyebab keragaman penampilan tanaman. Rata-rata diameter pangkal batang tanaman jagung manis pada umur 15, 30 dan 45 HST akibat perlakuan kedalaman lubang tanam disajikan pada Tabel 8 .

Tabel 8. Rata-rata Diameter Pangkal Batang Tanaman Jagung Manis akibat Perlakuan Kedalaman Lubang Tanam

\begin{tabular}{clll}
\hline \multirow{2}{*}{ Perlakuan } & \multicolumn{3}{c}{ Diameter Pangkal Batang $(\mathrm{mm})$} \\
\cline { 2 - 4 } & 15 HST & 30 HST & 45 HST \\
\hline $\mathrm{K}_{1}$ & 6,78 & 13,33 & 15,30 \\
$\mathrm{~K}_{2}$ & 7,00 & 13,56 & 15,37 \\
$\mathrm{~K}_{3}$ & 6,63 & 13,30 & 15,04 \\
$\mathrm{~K}_{4}$ & 6,59 & 12,81 & 14,63 \\
\hline
\end{tabular}

\section{Berat Tongkol Berkelobot per Tanaman (g)}

Hasil analisis ragam menunjukkan bahwa produksi tanaman jagung manis akibat 
perlakuan kedalaman lubang tanam menunjukkan respon yang nyata pada berat tongkol berkelobot per tanaman. Rata-rata berat tongkol berkelobot per tanaman jagung manis akibat perlakuan kedalaman lubang tanam disajikan pada Tabel 9.

Tabel 9. Rata-rata Berat Tongkol Berkelobot per Tanaman Jagung Manis akibat Perlakuan Kedalaman Lubang Tanam

\begin{tabular}{ll}
\hline Perlakuan & Berat Tongkol Berkelobot per Tanaman $(\mathrm{g})$ \\
\hline $\mathrm{K}_{1}$ & $372,96 \mathrm{ab}$ \\
$\mathrm{K}_{2}$ & $379,63 \mathrm{~b}$ \\
$\mathrm{~K}_{3}$ & $357,41 \mathrm{ab}$ \\
$\mathrm{K}_{4}$ & $351,48 \mathrm{a}$ \\
\hline BNJ 0,05 & 28,01 \\
\hline
\end{tabular}

Keterangan : Angka yang diikuti oleh huruf yang sama berbeda tidak nyata pada uji $\mathrm{BNJ}_{0,05}$

Tabel 9 menunjukkan bahwa berat tongkol berkelobot per tanaman jagung manis tertinggi dijumpai pada perlakuan $\mathrm{K}_{2}$ yang secara uji BNJ 0,05 berbeda nyata dengan perlakuaan $\mathrm{K}_{4}$, namun berbeda tidak nyata dengan perlakuan $\mathrm{K}_{1}$ dan $\mathrm{K}_{3}$. Pada kedalaman lubang tanam $5 \mathrm{~cm}$ didapatkan berat tongkol berkelobot tertinggi dibandingkan dengan kedalaman lubang tanam lain.

Hal tersebut karena kedalaman lubang tanam $5 \mathrm{~cm}$ merupakan kedalaman anjuran dalam budidaya jagung manis, sehingga menghasilkan pertumbuhan tanaman bagianbagian tanaman dengan baik serta dapat meningkatkan berat tongkol berkelobot tanaman jagung. Hal tersebut sesuai dengan pendapat Syukur dan Rifianto, (2002), penanaman jagung manis dilakukan secara manual dengan memasukkan benih ke dalam lubang pada kedalaman $5 \mathrm{~cm}$ yang dibuat dengan tugal atau diletakkan di larikan kemudian ditutup dengan tanah atau kompos.

\section{Berat Tongkol Tanpa Kelobot per Tanaman (g)}

Hasil analisis ragam menunjukkan bahwa produksi tanaman jagung manis akibat perlakuan kedalaman lubang tanam menunjukkan respon yang nyata pada berat tongkol tanpa kelobot per tanaman. Rata-rata berat tongkol tanpa kelobot per tanaman jagung manis akibat perlakuan kedalaman lubang tanam disajikan pada Tabel 10.

Tabel 10. Rata-rata Berat Tongkol Tanpa Kelobot per Tanaman Jagung Manis akibat Perlakuan Kedalaman Lubang Tanam

\begin{tabular}{cl}
\hline Perlakuan & Berat Tongkol Tanpa Kelobot per Tanaman $(\mathrm{g})$ \\
\hline $\mathrm{K}_{1}$ & $288,52 \mathrm{ab}$ \\
$\mathrm{K}_{2}$ & $293,70 \mathrm{~b}$ \\
$\mathrm{~K}_{3}$ & $272,59 \mathrm{ab}$ \\
$\mathrm{K}_{4}$ & $263,70 \mathrm{a}$ \\
\hline BNJ 0,05 & 29,19
\end{tabular}

Keterangan : Angka yang diikuti oleh huruf yang sama berbeda tidak nyata pada uji $\mathrm{BNJ}_{0,05}$

Tabel 10 menunjukkan bahwa berat tongkol tanpa kelobot per tanaman jagung manis tertinggi dijumpai pada perlakuan $\mathrm{K}_{2}$ yang secara uji $\mathrm{BNJ} 0,05$ berbeda nyata dengan perlakuaan $\mathrm{K}_{4}$, namun berbeda tidak nyata dengan perlakuan $\mathrm{K}_{1}$ dan $\mathrm{K}_{3}$. Hal tersebut 
diduga pada kedalam penanaman $5 \mathrm{~cm}$ merupakan kedalaman yang optimum, sehingga dapat meningkatkan berat tongkol tanpa kelobot tanaman jagung manis. Hal tersebut sesuai dengan hasil penelitian Pratama $d d k$., (2014), didapatkan bahwa dari beberapa kedalam penanaman jagung manis yang diuji yaitu 1,3,5 dan $7 \mathrm{~cm}$, berat tongkol tanpa kelobot tertinggi didapatkan pada kedalaman lubang tanaman $5 \mathrm{~cm}$ yaitu 222,30 g.

\section{Panjang Tongkol (cm)}

Hasil analisis ragam menunjukkan bahwa produksi tanaman jagung manis akibat perlakuan kedalaman lubang tanam menunjukkan respon yang nyata pada panjang tongkol. Rata-rata panjang tongkol tanaman jagung manis akibat perlakuan kedalaman lubang tanam disajikan pada Tabel 11. 
Tabel 11. Rata-rata Panjang Tongkol Tanaman Jagung Manis akibat Perlakuan Kedalaman Lubang Tanam

\begin{tabular}{cc}
\hline Perlakuan & Panjang Tongkol $(\mathrm{cm})$ \\
\hline $\mathrm{K}_{1}$ & $20,76 \mathrm{ab}$ \\
$\mathrm{K}_{2}$ & $21,41 \mathrm{~b}$ \\
$\mathrm{~K}_{3}$ & $20,53 \mathrm{ab}$ \\
$\mathrm{K}_{4}$ & $19,96 \mathrm{a}$ \\
\hline BNJ 0,05 & 1,13 \\
\hline
\end{tabular}

Keterangan : Angka yang diikuti oleh huruf yang sama berbeda tidak nyata pada uji $\mathrm{BNJ}_{0,05}$

Tabel 11 menunjukkan bahwa panjang tongkol tanaman jagung manis tertinggi dijumpai pada perlakuan $\mathrm{K}_{2}$ yang secara uji BNJ 0,05 berbeda nyata dengan perlakuaan $\mathrm{K}_{4}$, namun berbeda tidak nyata dengan perlakuan $\mathrm{K}_{1}$ dan $\mathrm{K}_{3}$. Hal tersebut diduga pada kedalaman penanaman $5 \mathrm{~cm}$ merupakan kedalaman lubang tanam yang optimum sehingga dapat meningkatkan perkembangan tongkol berupa tongkol yang lebih panjang.

Menurut Santoso dan Purwoko, (2008), untuk kedalaman tanam yang baik, pembentukan mesocotyl dan akar adventif dapat terbentuk dengan baik, pada kedalaman yang terlalu dalam dari permukaan tanah, maka coleoptyle akan kering di dalam tanah tanpa membentuk akar adventif yang berakibat bibit dan tanaman tumbuh tidak normal.

\section{Produksi per Plot (kg)}

Hasil analisis ragam menunjukkan bahwa produksi tanaman jagung manis akibat perlakuan kedalaman lubang tanam menunjukkan respon yang nyata pada produksi per plot. Rata-rata produksi per plot tanaman jagung manis akibat perlakuan kedalaman lubang tanam disajikan pada Tabel 12.

Tabel 12. Rata-rata Produksi per Plot Tanaman Jagung Manis akibat Perlakuan Kedalaman Lubang Tanam

\begin{tabular}{ll}
\hline Perlakuan & Produksi per Plot $(\mathrm{kg})$ \\
\hline $\mathrm{K}_{1}$ & $1,61 \mathrm{ab}$ \\
$\mathrm{K}_{2}$ & $1,71 \mathrm{~b}$ \\
$\mathrm{~K}_{3}$ & $1,56 \mathrm{ab}$ \\
$\mathrm{K}_{3}$ & $1,50 \mathrm{a}$ \\
\hline BNJ 0,05 & 0,16
\end{tabular}

Keterangan : Angka yang diikuti oleh huruf yang sama berbeda tidak nyata pada uji $\mathrm{BNJ}_{0,0}$

Tabel 12 menunjukkan bahwa produksi per plot tanaman jagung manis tertinggi dijumpai pada perlakuan $\mathrm{K}_{2}$ yang secara uji $\mathrm{BNJ}$ 0,05 berbeda nyata dengan perlakuaan $\mathrm{K}_{4}$, namun berbeda tidak nyata dengan perlakuan $\mathrm{K}_{1}$ dan $\mathrm{K}_{3}$. Hal tersebut diduga pada kedalaman $5 \mathrm{~cm}$, benih yang ditaman memiliki vigor dan pertumbuhan awal tanaman yang baik, sehingga dapat meningkatkan produksi tanaman jagung

Hal tersebut sesuai dengan pendapat Pratama $d k k$., (2014) kedalaman tanam berhubungan dengan vigor tanaman, bibit normal dari benih yang memiliki kekuatan tumbuh yang baik pada kedalaman optimal namun sebaliknya jika kedalaman kurang optimal benih tidak akan tumbuh dengan baik karena benih memerlukan ruang yang optimal agar dapat berkecambah, tumbuh serta menghasilkan produksi yang optimal. 


\section{Respon Pertumbuhan dan Produksi Jagung Manis akibat Jarak Tanam dan Lubang Tanam}

Hasil Analisis Ragam menunjukkan bahwa interaksi antara jarak tanam dan kedalaman lubang tanam, pengaruh nyata terhadap parameter tinggi tanaman umur 30 HST, sedangkan untuk parameter yang lain tidak menunjukkan respon yang nyata. Ratarata tinggi tanaman jagung manis umur 30 HST akibat respon interaksi antara jarak tanam dan kedalaman lubang tanam disajikan pada Tabel 13.

\begin{tabular}{|c|c|}
\hline Perlakuan & Tinggi Tanaman Umur 30 HST $(\mathrm{cm})$ \\
\hline $\mathrm{J}_{1} \mathrm{~K}_{1}$ & $41,11 \mathrm{a}$ \\
\hline $\mathrm{J}_{1} \mathrm{~K}_{2}$ & $40,77 \mathrm{a}$ \\
\hline $\mathrm{J}_{1} \mathrm{~K}_{3}$ & $38,78 \mathrm{a}$ \\
\hline $\mathrm{J}_{1} \mathrm{~K}_{4}$ & $39,57 \mathrm{a}$ \\
\hline $\mathbf{J}_{2} \mathrm{~K}_{1}$ & $41,72 \mathrm{ab}$ \\
\hline $\mathrm{J}_{2} \mathrm{~K}_{2}$ & 41,48 a \\
\hline $\mathrm{J}_{2} \mathrm{~K}_{3}$ & $43,23 \mathrm{ab}$ \\
\hline $\mathrm{J}_{2} \mathrm{~K}_{4}$ & 39,26 a \\
\hline $\mathrm{J}_{3} \mathrm{~K}_{1}$ & $43,90 \mathrm{ab}$ \\
\hline $\mathrm{J}_{3} \mathrm{~K}_{2}$ & $48,77 \mathrm{~b}$ \\
\hline $\mathrm{J}_{3} \mathrm{~K}_{3}$ & $41,77 \mathrm{ab}$ \\
\hline $\mathrm{J}_{3} \mathrm{~K}_{4}$ & $39,01 \mathrm{a}$ \\
\hline $\mathrm{BNJ}_{0,05}$ & 7,16 \\
\hline
\end{tabular}

Keterangan : Angka yang diikuti oleh huruf yang sama berbeda tidak nyata pada uji $\mathrm{BNT}_{0,05}$.

Tabel 13 menunjukkan tinggi tanaman jagung manis umur 30 HST tertinggi dijumpai pada perlakuan $\mathrm{J}_{3} \mathrm{~K}_{2}$ (jarak tanam $70 \times 50 \mathrm{~cm}$ dan kedalaman lubang tanam 5 $\mathrm{cm}$ ) yang secara uji $\mathrm{BNJ}_{0,05}$ berbeda nyata dengan perlakuan $\mathrm{J}_{1} \mathrm{~K}_{1}, \mathrm{~J}_{1} \mathrm{~K}_{2}, \mathrm{~J}_{1} \mathrm{~K}_{3}, \mathrm{~J}_{1} \mathrm{~K}_{4}, \mathrm{~J}_{2} \mathrm{~K}_{2}$, $\mathrm{J}_{2} \mathrm{~K}_{4}$ dan $\mathrm{J}_{3} \mathrm{~K}_{4}$, namun berbeda tidak nyata dengan perlakuan $\mathrm{J}_{2} \mathrm{~K}_{1}, \mathrm{~J}_{2} \mathrm{~K}_{3}, \mathrm{~J}_{3} \mathrm{~K}_{1}$ dan $\mathrm{J}_{3} \mathrm{~K}_{3}$. Hal ini diduga pada kombinasi perlakuan jarak tanam 70 x $50 \mathrm{~cm}$ dan kedalaman lubang tanam $5 \mathrm{~cm}$ ketersediaan penyerapan unsur hara yang lebih oiptimal dibandingkan dengan kombinasi perlakuaan yang lain, sehingga tanaman yang dihasilkan lebih tinggi dibandingkan dengan kombinasi perlakuan lain. Pada kedalaman lubang tanam yang optimal, perakaran tanaman tumbuh dengan baik sehingga penyerapan air dan unsur hara untuk proses metabolisme terjadi dengan baik.

Jarak tanam merupakan salah satu hal terpenting dalam budidaya karena mempengaruhi penyerapan hara, air, cahaya. Keuntungan yang akan didapatkan jika menggunakan jarak tanam yang tepat adalah meningkatkan penerimaan intensitas cahaya matahari pada daun dan diharapkan hasil asimilat meningkat sehingga pertumbuhan tanaman dan pengisian biji dapat optimal, serta memudahkan pemeliharaan tanaman, terutama penyiangan gulma baik secara manual maupun dengan herbisida, pemupukan, serta pemberian air (Balitsereal, 2013 dalam Syarifah, 2015).

Menurut Sitompul dan Guritno (1995) peran akar dalam pertumbuhan tanaman 
sama pentingnya dengan tajuk, tajuk berfungsi untuk menyediakan karbohidrat melalui proses fotosintesis, maka fungsi akar adalah menyediakan unsur hara dan air yang diperlukan dalam metabolisme tanaman.

\section{KESIMPULAN}

1. Pertumbuhan dan produksi tanaman jagung manis akibat perlakuan jarak tanam menunjukkan respon yang nyata terhadap tinggi tanaman umur (30 dan $45 \mathrm{HST}$ ), berat tongkol berkelobot per tanaman, berat tongkol tanpa kelobot per tanaman, panjang tongkol, dan produksi per plot, sedangkan parameter lainnya menunjukkan respon yang tidak nyata. Perlakuan jarak tanam terbaik adalah 70 x $50 \mathrm{~cm}\left(\mathrm{~J}_{3}\right)$.

2. Pertumbuhan dan produksi tanaman jagung manis akibat perlakuan kedalaman lubang tanam menunjukkan respon yang sangat nyata terhadap tinggi tanaman umur 30, respon nyata terhadap tinggi tanaman umur (15 dan 45 HST), berat tongkol berkelobot per tanaman, berat tongkol tanpa kelobot per tanaman, panjang tongkol dan produksi per plot, sedangkan parameter lainnya menunjukkan respon yang tidak nyata. Perlakuan kedalaman lubang tanam terbaik adalah $5 \mathrm{~cm}\left(\mathrm{~K}_{2}\right)$.

3. Interaksi antara jarak tanam dan kedalaman lubang tanam memberikan respon yang nyata terhadap parameter tinggi tanaman umur 30 HST. Kombinasi perlakuan terbaik yaitu $\mathrm{J}_{3} \mathrm{~K}_{2}$ (jarak tanam $70 \times 50 \mathrm{~cm}$ dan kedalaman lubang tanam $5 \mathrm{~cm}$ ).

\section{DAFTAR PUSTAKA}

Adji, S. 2007. Rancangan Percobaan Praktis Bidang Pertanian. Kanisius. Yogyakarta.

Azis, A. H., Arman. 2013. Respons Jarak Tanam dan Dosis Pupuk Organik Granul yang Berbeda terhadap Pertumbuhan dan Produksi Tanaman Jagung Manis. $J$. Agrisistem. 9 (1):16-23.

Dwijoseputro, D. 1991. Pengantar Fisiologi Tumbuhan. Gramedia. Jakarta. Dzwonko, Z., S. Gawronski. 2002. Influence of Litter and Weather on Seedling

Recruitment in a Mixed Oak-Pine Woodland. Ann. Bot. (90) : 245-251.

Gardner, F. 1991. Fisiologi Tanaman Budidaya. Universitas Indonesia Press (UIP), Jakarta.

Harjadi, S, S. M. M., 2002. Pengantar Agronomi. Gramedia Pustaka Utama. Jakarta. 